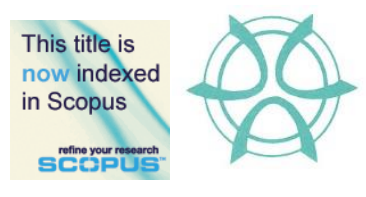

PLANNING MALAYSIA:

Journal of the Malaysian Institute of Planners

VOLUME 15 ISSUE 2 (2017), Page 1 - 12

\title{
URBAN PLANNING AND THE CHALLENGES OF NEOLIBERAL GLOBALISATION IN MALAYSIA
}

\author{
Marlyana Azyyati Marzukhi ${ }^{1}$, Oliver Ling Hoon Leh ${ }^{2}$, \& Hazlina Hamdan ${ }^{3}$ \\ ${ }^{1,2,3}$ Faculty of Architecture, Planning and Surveying \\ UNIVERSITI TEKNOLOGI MARA (UiTM)
}

\begin{abstract}
Popularly referred to as an Asian Tiger, planning for economic development has been a significant feature in the Malaysian planning system. This reflected the historical junctures that transform Malaysia economy from agricultural potential to industrial capabilities. The rapid industrialisation that can be linked to neoliberal ideology has caused people to migrate from rural to urban area that echoed the emergence of urban settlements. However, this transformation has produced social and environmental instability, as a result of capital accumulation. Accordingly, this study conducted in-depth interviews and documents analysis, with the objective to develop understanding of how neoliberal globalisation rationalises the emergence of urban settlements in Malaysia through its policies and planning practice. The Nvivo10 was used to define categories and synthesise the ideas from the interview data and planning policy documents. This paper is expected to contribute to deepening knowledge of the emergence of urban settlements particularly in the urban planning field under the pervasive discourse of neoliberal globalisation.
\end{abstract}

Keywords: planning, practice, policies, neoliberal globalisation, urban settlements

Date Received: $26^{\text {th }}$ July 2016

Date of Acceptance: $6^{\text {th }}$ July 2017 
Marlyana Azyyati Marzukhi, Oliver Ling Hoon Leh, \& Hazlina Hamdan

Urban Planning and the Challenges of Neoliberal Globalisation in Malaysia

\section{INTRODUCTION}

In the early twenty-first century, discussion on planning seems to revolve around aspects of globalisation that are associated with the ideology called neoliberalism (for examples see Allmendinger \& Haughton, 2013; Clifford \& Tewdwr-Jones, 2013). The current processes of globalisation are undergoing a shift toward market-led development, by transferring much of the authority of the state to a new process of governing, which leads to the triumph of market control over the democratic process (Dean, 2010). The significance given to market control is embedded in the expression of capitalism, in which the objective is to maximize profit in a market economy (Bellanca, 2013). One of the elements central to capitalism is the ability to promote economic growth, which is measured by its per capita Gross Domestic Product (GDP) (Gunder \& Hillier, 2009). In light of this, planning for economic development has become a significant feature of rapid urban transformation under the hegemony of neoliberalism (Purcell, 2013).

As is true in other western countries, neoliberal globalisation has marked a significant departure from the mode of governance in Malaysia as its development has "become more integrated into global economic regimes" (Turner et al., 2013, p. 490). This gives rise to the perception that the neoliberal globalisation has effectively contributed to market-led initiatives in the development of Malaysia. Furthermore, the globalisation trend has inspired Malaysia "to be fully developed by the year 2020", which is also outlined in Malaysia's affirmative policy, Vision 2020. The transition is evident in the form of urban settlements that have emerged in Malaysia through the transformation of its policies and institutions.

Significantly, "Malaysia has been successful in transforming its economy by effectively developing its industrial capabilities and exploiting its agricultural potential through government action at various level" and a recognition of changing international trends (Dadzie, 2013, p. 147). In fact, the rapid industrialisation in Malaysia has driven population migration to major cities such as Kuala Lumpur, which, in turn, has caused an impact on housing demand. Further, the continued rise of the Malaysian housing market has led to the practices of "privatisation, free market policies and financial liberalisation" (Tedong et al., 2015, p. 117). In a similar vein, Khair et al. (2015, p. 230) highlighted that rapid industrialisation has also led to a "privatisation agenda with the rhetoric of matching other Asian Tigers [Singapore, Hong Kong, South Korea and Taiwan] regardless of the impact on the democratic process."

However, this high growth has come with a heavy price, primarily in the form of social injustice and deterioration of the environment (Maidin, 2012b). This matter has been highlighted in a number of very serious cases, which 
PLANNING MALAYSIA

Journal of the Malaysia Institute of Planners (2017)

involved both the public and local governance. Almost daily newspapers report incidents of inappropriate development resulting in landslides, rivers being seriously polluted, and flash floods that often lead to massive traffic jams and unsustainable conditions in the country. Therefore, it is a challenge to contemporary planning to produce economic and social stability because neoliberalism "has increasingly shaped state policy to benefits capital rather than citizens" (Purcell, 2009, p. 143) and "often tends to overemphasize economic values above social justice goals and environmental concerns" (Kumi, Arhin \& Yeboah, 2014, p. 6).

Thus, it is very clear what this tendency exemplify: neoliberal globalisation justify the emergence of urban settlements in Malaysia through its policies, which brings further challenges in the Malaysian planning system. Considering all the foregoing together, the understanding of the historical juncture of Malaysia and addressing the way in which its practice has evolved in planning, offers a useful insight into the ways of the state reform and change the socio-economic landscape of the country. Indeed, as Maidin (2012a, p. 3) argues, the development of Malaysia since independence, in fact, explains "the evolution of the town and country planning law and administrative system [that] provides background information on the development of Malaysian town and country planning regulation, administration and procedures". This argument provides the background to the development of the Malaysian planning system at the time when the country was a British colony.

\section{HISTORICAL JUNCTURES OF ECONOMIC RESTRUCTURING IN MALAYSIA}

Malaysia gained its independence from Britain in 1957. Under British colonisation, the Chinese, Indians and Malays were segregated according to the racial origin and ethnic groups. Following independence from British rule, the Malays and Chinese felt the rising of racial tension as a result of the wide disparity of income between the various ethnic groups; this culminated in the riots of $13^{\text {th }}$ May 1969 (Bruton, 2007). Following the riots, in an attempt to restructure the socio-economic disparity between Malays and the non-Malays, the government introduced the New Economic Policy (NEP) (1971-1990) to restructure the socioeconomic gaps between Malays and the non-Malays (Gomez, 2005).

However, the restructuring and implementation of policies were seen as promoting the economic interests of the Malays, which created a state of constant tension among non-Malays. This was a critical juncture in Malaysia's history because this affirmative action policy to some extent explains the socio-economic transition in Malaysia. Also, the policy served to turn governance attention to the 
Marlyana Azyyati Marzukhi, Oliver Ling Hoon Leh, \& Hazlina Hamdan

Urban Planning and the Challenges of Neoliberal Globalisation in Malaysia

reshaping of the structure of multi-ethic groups and this further affected Malaysia's economic stability. Reflecting on this, Tedong et al. (2015, p. 116) claim that NEP:

...not only bridged the gap in income between Malays and non-Malays, but revealed the determination of the [governance] to enact [the] quasineoliberal policies [that had been in place] before the era of neoliberalism came to dominate the West.

As such, over the years, the NEP had been successful in facilitating economic growth in Malaysia by evolving from being an agricultural nation into an industrial one (Brooker, 2012).

The NEP ended in 1990. Following this, efforts by the Malaysian government to restructure the socio-economics of the country have been incorporated in the new National Development Policy (NDP) to replace the NEP and the New Economic Model (NEM), as well as in other existing instruments such as the Outline Perspective Plan and the Malaysia Plan (national five-year development plans). All the plans were imposed by the federal government to provide an affirmative action policy for the socio-economic agenda. Hence, it is not the intention of this paper to delve deeply into all the policies and plans. Instead, the emphasis here is to provide an understanding of the governance of Malaysian administrative framework in general that regulates matters pertaining to the urban planning system in Malaysia. Here, the Malaysia Plan is of significance as it has been used to endorse the various socio-economic plans of the country for every five year period, starting from the First Malaysian Plan (1966-1970) until the current Eleventh Malaysian Plan (2016-2020) (Economic Planning Unit, 2015). Accordingly, under the Fourth Malaysian plan (19811985), Malaysia's development coincided with global neoliberalisation and, typically, "made a transition from a state-dominated developmentalist towards a free-market model" (Tedong et al., 2015, p. 117).

In 1997-1998, Malaysia faced the Asian financial crisis. This also changed the socio-economic landscape of the country through government bail-outs and more privatisation (Khair et al., 2015). Further, the global recession in 2008 caused 'major shocks' in Malaysia (Athukorala, 2012). However, Malaysia has resonated well throughout the crises.

The arguments also align well with Qadeer (2012, p. 225), that emphasises the manifestation of high-rise development in Malaysia that "are frequently inspired by images of Western 'prestigious cities'... [and this visualization] continues to inspire the [local] elites" to privilege market over social imperatives. Reflecting this, "a grandiose utopian" development such as the Kuala Lumpur 
PLANNING MALAYSIA

Journal of the Malaysia Institute of Planners (2017)

City Centre (KLCC) and Kuala Lumpur International Airport (KLIA) were built in a way that "became symptomatic of 'boom-time' in Malaysia" (Brooker, 2012, p. 41). This suggests that Malaysia "has benefited from, and has also been adversely affected by, neoliberal globalisation" as claimed by Chin (2000, p. 1037) a decade ago.

Consequently, little is known about the effect of neoliberal globalisation on the Malaysian planning system, whether from a theoretical or empirical point of view. Allied to this, this paper argues that the planning system in Malaysia need to be analysed in the context of these overall processes of evolution, in terms of ways it (dis)engages with neoliberal globalisation which affecting urban settlements in Malaysia. Therefore, whether, or not, and to what extent the neoliberal globalisation has instigated urban settlements in Malaysia is further examined in the following sections.

\section{THE EMERGENCE OF URBAN SETTLEMENTS: ISSUES AND CHALLENGES}

Considering all the foregoing together, the growth of economy as a result of industrialisation has influenced population migration and caused significant settlement in the urban areas. Urban area refers to an area "which at least has a population of 10,000 with at least $60 \%$ of population (aged 15 years and above) were involved in non-agricultural activities" (Department of Statistic Malaysia, 2015). Further, "the increasing number of people that migrate from rural-to-urban areas" leads to the process of urbanisation (United Nation, 2008). This changing trend also appears to foresee why people prefer to live in the urban area that includes the employment, education, standard of the geographical condition which has impacts on people quality of life (Chowdhury \& Mavrotas, 2005). As such, all the opportunities have become the 'push and pull factors' that influence people to migrate from rural to urban. This aspect bears important interpretive implications that reflect the relationship between people movement to the urban area and the economy as one of the main factors for the rapid growth of the country (Gugler, 1997).

Reflecting this, to achieve a fully developed country by 2020, governance practice plays an essential role in facilitating "the economic activity to create new values [and] make the difference in the Malaysian economic fundamentals" (Ahmed, 2012, p. 1503; see also Taib \& Siong, 2008). The private sector, demand-driven land development activities have become significant contributors to the growth of GDP of the country (Hitam \& Borhan, 2012). This perspective clarifies that the impact of neoliberal globalisation has influenced government to use 'governance tools' such as policies and legislations to guide the economic 
Marlyana Azyyati Marzukhi, Oliver Ling Hoon Leh, \& Hazlina Hamdan

Urban Planning and the Challenges of Neoliberal Globalisation in Malaysia

development. However, with the progress of development, Maidin (2011, p. 163) states:

It appears that the planning authorities are very concerned in ensuring successful implementation of the country's development policies formulated to boost the economic rather than taking into consideration the effect of such activities on the environment and the public.

This implies that economic development has become a concern of the core planning system, which seems to uphold the neoliberals' domination of economic values that are concerned with the direction of conduct for certain ends. Following this, the notion of neoliberal globalisation demonstrates and justifies how the planning practice, in maintaining the economic growth of the country, has contributed to the emergence of urban settlements in Malaysia. Likewise, these perspectives have led to the production of housing development which often transcend the public-private partnership in the Malaysian governance. In fact, "the involvement of the private sector in housing markets in Malaysia coincided with the international rise of neoliberalism" (Tedong et al., 2015, p. 117). However, the proliferation of 'too much' development in the urban area has caused environmental degradation and uncontrolled development. As Bruton (2007, p. 28) succinctly commented:

Malaysia's strong economic position has come at a cost to the environment...... Much of Malaysian jungle has been cleared, on a scale comparable with that in the Amazon basin, but in a much shorter timescale.

What is at stake here expresses the dimension on the use of land to develop a range of housing development to cater the population settlements in the urban area. Also, this status brings further challenges to planning to balance social, economic and environmental well-being in this twenty-first century. Therefore, it is vital to justify the degree of neoliberalism's influence in planning which fundamentally reflects the issues of urban settlement through the value of planning policy instruments in Malaysia.

\section{RESEARCH METHODOLOGY}

The methodology deployed in this study was mixed-method qualitative in nature and guided by Flyvbjerg, Landmann and Schram's (2012) phronetic social science approach. The emphasis on the context and process of this methodology was reflected in the technique from grounded theory. In this sense, the paper emphasizes the understanding on how the social world operates and "what makes [something] happen as they do" (Neuman, 2012, p. 28). A case study was selected 
PLANNING MALAYSIA

Journal of the Malaysia Institute of Planners (2017)

to map out the form of a narrative inquiry, which included in-depth interview and written description, which can create a more particular and contextualised version of the research (Savin-Baden \& Major, 2013).

This research adopted an in-depth interviewing method and open-ended questions, which focused on how planners and other stakeholders react towards neoliberal globalisation, including the value judgements on the use of planning policy documents. A total of twenty participants were selected based on purposeful sampling in relation to the social background and personality of those actively engaged in the planning process, as well as the professional status of planners as opposed to other actors (developers, the public and politicians). Hence, eight planners from the local authorities, four local councillors, two Members of Parliament, two developers and four representatives from community groups were chosen.

Additionally, the research used documents from secondary sources for the analysis; these are presented in the form in which they were originally printed. The type of document analysis used was significant as it "can be considered to represent actors in their own right" (Prior, 2008, p. 232). This was in line with the idea of "discourse as a system of representation" in which "the rules and practices [may] produce meaningful statements and regulated discourse in different historical periods" (Hall, 2001, p. 72). The analysis contributed to a deepening knowledge of the ways in which neoliberalism is adopted as it focuses on a limited realm of phenomena that have been fragmented by the changing bases of state power.

The selected cases were the Federal Territory of Kuala Lumpur and Selangor. The relevant documents collected included; the Eleventh Malaysia Plan (2016-2020), the National Physical Plan, the Kuala Lumpur Structure Plan 2020, Petaling Jaya Local Plan 1, the Town and Country Planning Act 1976 and newspaper articles. In fact, media content such as newspapers is significant to reflect social reality, in which by "studying content helps us infer things about phenomena that are less open and visible" (Shoemaker \& Reese, 2013, p. 24). Also, it can provide a "range of verbal and visual information distributed by the mass media - in other words, just about anything that appears there" (p. 4).

The data analysis justifies the merits of using grounded theory in analysing data from interview and planning documents. The analysis was focussed on a constant comparison of data, codes and the theoretical categories (Bryant \& Charmaz, 2007). Therefore, through the analysis of all the interview data and documents, the patterns and outcomes rationalise the evidence found. To illustrate the process of data analysis, it begins with a line-by-line coding from the interview and written text in order to form descriptive categories, which in 
Marlyana Azyyati Marzukhi, Oliver Ling Hoon Leh, \& Hazlina Hamdan

Urban Planning and the Challenges of Neoliberal Globalisation in Malaysia

turn are used to analyse the emerging theoretical reflections. The codes and their relationship to other codes are compared and analysed to establish the values with the core categories. These categories were defined by using Nvivo10 to assist in the managing and synthesizing of the ideas gathered from the analysis.

\section{FINDINGS AND DISCUSSIONS}

The findings reflected the views, at least of the participants, that there is a clear connection between the practice of governance and neoliberalism in the Malaysian planning system. This indicated the "economic openness" of the country "as evidenced by the rapid pace of economic growth and development", which accords with Ahmed (2012, p. 1499). Significantly, the Malaysian policies display the significance and influence of economic objectives in their contents, such as in the Malaysia Plan and the development plans. For instance, the Federal Territory of Kuala Lumpur and Selangor were the two states with the highest growth of GDP in 2010, and this is expected to increase even more by the year 2020 (Economic Planning Unit, 2015). This reflects the positioning of Malaysian governance to drive rapid growth particularly in the context of economic development, which attracts more urban settlements in these states.

Following this, to best understand how planning has been practiced, whether it is (un)intentionally reoriented towards the neoliberal agenda, the following question was asked to the participants: What do you think is the core concern of the Malaysian planning system? One participant claimed: "The authority allows vertical development and high-density development that is making development more compounded. They want to portray the city as a world class city" (Interview, 7 May 2015). Typically, the public views economic considerations as the core concern in the planning process, which have (in)direct influences in planning practice. Reflecting this, for planners to carry out the national goals, they must be assigned roles through which practice can meet the needs and aspirations of the country. As one planner commented: "When we process planning permission, we are bound with the development plans and the Act." (Interview, 7 May 2015). These statements were supported by other planners. This highlighted that planners must consider other planning mechanisms to legitimate their actions in the decision-making. What this seems to suggest is that planners strive to reach their goal by providing a formal strategy as evidence of their practices.

Reflecting this, based on the identity to be 'a world class-city', this suggests that the image of the Malaysian planning system which directed towards economic development somehow impacts the emergence of urban settlements in both states. In fact, statistics showed an increase of urban population in Kuala 
PLANNING MALAYSIA

Journal of the Malaysia Institute of Planners (2017)

Lumpur from 1.42 million in 2000 to an estimated 1.72 million in 2013, and in Selangor from 4.18 million in 2000 to an estimated 5.90 million in 2013 (Department of Statistic Malaysia, 2015). As such, the planning instruments has effected in delivering and regulating land use planning in Malaysia.

With the Town and Country Planning Act (1976) as the principal statute regulating town and country planning practices for the Peninsular Malaysia, the ultimate authoritative document for land use planning are to the development plans (Maidin, 2012b). All development plans are used to assist the Federal and State governments to draw up development policies. In fact, "[t]hese plans are also intended to provide a logical extension to the socio-economic policies of the country as outlined in the country's Five Year National Development Plan" (Taib $\&$ Siong, 2008, p. 5). Reflecting this, for planners to carry out the national goals, they must be assigned roles through which practice can meet the needs and aspirations of the country. In this sense, the planning policies can be seen as the results of economic domination that materializes the neoliberal values of globalisation set via the practice of governance. Alongside this, there is an ongoing struggle in planning; this struggle is to find a balance of economic, social and environmental well-being (Porter et al., 2013).

Accordingly, the culmination is that planners, being part of the process of transformation, are well-placed to engage and respond to the pace and extent of urban settlement in Malaysia. Here perhaps, after more than 20 years, planning still needs an account of what the practice of the planner is all about in this contemporary governance; this is because planning itself has evolved (Van Assche, Beunen \& Duineveld, 2014). Certainly, this demonstrates and justifies how planning and the planning profession itself engage and transform in response to the conflict underpinned by neoliberal globalisation. The merits attributed to the way in which the progress of Malaysia's economic growth and the historical background of economic restructuring in Malaysia have influenced the process of adopting the neoliberal ideology in the Malaysian planning system, which in some ways allows for the emergence of urban settlements in Malaysia.

\section{CONCLUSION}

The understanding of the historical junctures of Malaysia can provide a basis for the migration of people from rural to urban area in response to the dominance of neoliberalism; this is because governance practice is always subject to an evolutionary perspective. Following this, the development of housing area in Malaysia represents physical manifestations of the economic growth of the country via the implementation of planning policy documents. In this sense, neoliberal globalisation certainly gives rise for enabling urban settlement as can 
Marlyana Azyyati Marzukhi, Oliver Ling Hoon Leh, \& Hazlina Hamdan

Urban Planning and the Challenges of Neoliberal Globalisation in Malaysia

be seen in the area of Kuala Lumpur and Selangor. However, the process brings further challenges to the Malaysian planning system such as social injustice and environmental deterioration. Reflecting this, the understanding of planning practice helps to demonstrate on how planners accommodate neoliberal globalisation.

\section{ACKNOWLEDGEMENTS}

The authors would like to thank Universiti Teknologi MARA, all the government departments, organisations and individuals who have contributed to this study.

\section{REFERENCES}

Ahmed, E. M. (2012). Are the FDI inflow spillover effects on Malaysia's economic growth input driven? Economic Modelling, 29(4), 1498-1504.

Allmendinger, P., \& Haughton, G. (2013). The evolution and trajectories of English spatial governance: 'Neoliberal'episodes in planning. Planning Practice \& Research, 28(1), 6-26.

Athukorala, P. C. (2012). The Malaysian economy during three crises. In H. Hill, S. Y. Tham \& Mat Zin, R. (Eds.), Malaysia's development challenges: graduating from the middle (pp. 83-105). Oxon: Routledge.

Bellanca, N. (2013). Capitalism. In L. Bruni \& S. Zamagni (Eds.), Handbook on the economics of reciprocity and social enterprise (pp. 59-67). Cheltenham, United Kingdom: Edward Elgar.

Brooker, D. (2012). Build it and they will come? A critical examination of utopian planning practices and their socio-spatial impacts in Malaysia's intelligent city. Asian Geographer, 29(1), 39-56.

Bruton, M. J. (2007). Malaysia: the planning of a nation. Malaysia: PERSADA.

Bryant, A., \& Charmaz, K. (Eds.) (2007). The Sage handbook of grounded theory. London: Sage.

Chin, C. B. N. (2000). The state of the 'state' in globalization: social order and economic restructuring in Malaysia. Third World Quarterly, 21(6), 10351057.

Chowdhury, A., \& Mavrotas, G. (2005). FDI and growth: a causal relationship (No. 2005/25). Research Paper, UNU-WIDER, United Nations.

Clifford, B. \& Tewdwr-Jones, M. (2013). The collaborating planner? Practitioners in the neoliberal age. Bristol, United Kingdom: The Policy Press.

Dadzie, R. B. (2013). Economic development and the developmental state: assessing the development experiences of Ghana and Malaysia since independence. Journal of Developing Societies, 29(2), 123-154.

Dean, M. (2010). Governmentality: power and rule in modern society (2nd ed.). London: Sage Publication Ltd. 
PLANNING MALAYSIA

Journal of the Malaysia Institute of Planners (2017)

Department of Statistics Malaysia (2015). Population and demography. Retrieved from http://www.statistics.gov.my.

Economic Planning Unit (2015). Eleventh Malaysia Plan (2016-2020). Retrieved from http://www.epu.gov.my.

Flyvbjerg, B., Landmann, T., \& Schram, S. (Eds.) (2012). Real social science: applied phronesis. Cambridge: Cambridge University Press.

Gomez, E. T. (2005). The state, governance, and corruption in Malaysia. In N. Tarling (Ed.), Corruption and good governance in Asia (pp. 214-244). Oxon: Routledge.

Gugler, J. (1997). Cities in the developing world: issues theory and policy. New York: Oxford University Press.

Gunder, M., \& Hillier, J. (2009). Planning in ten words or less: A Lacanian entanglement with spatial planning. Surrey, England: Ashgate.

Hall, S. (2001). Foucault: power, knowledge and discourse. In M. Wetherell, \& S. Taylor \& S. J. Yates (Eds.), Discourse theory and practice: a reader (pp. 72-81). London: SAGE Publications Ltd.

Hitam, M., \& Borhan, H. (2012). FDI, growth and the environment: impact on quality of life in Malaysia. Procedia-Social and Behavioral Sciences, 50, 333-342.

Khair, A. H. A., Haniffa, R., Hudaib, M., \& Karim, M. N. A. (2015), Personalisation of power, neoliberalism and the production of corruption. Accounting Forum, 39(3), 225-235.

Kumi, E., Arhin, A. A., \& Yeboah, T. (2014). Can post-2015 sustainable development goals survive neoliberalism? A critical examination of the sustainable development-neoliberalism nexus in developing countries. Environment, Development and Sustainability, 16(3), 539-554.

Maidin, A. J. (2011). Access to public participation in the land planning and environmental decision making process in Malaysia. International Journal of Humanities and Social Science, 1(3), 148-164.

Maidin, A. J. (2012a). Malaysian town and country planning: law and procedure. Malaysia: CLJ Publication.

Maidin, A. J. (2012b). Development Plans Role in Promoting Achievement of Sustainable Development: A Case Study of the State of Selangor, Malaysia. Retrieved from https://ssrn.com/abstract=1992191.Neuman, W. L. (2012). Basics of social research: qualitative and quantitative approaches. Pearson.

Porter, L., Martí-Costa, M., Torvà, M. D., Cohen-Bar, E., Ronel, A., Rogers, D., \& Gibson, C. (2013). Finding hope in unpromising times: stories of progressive planning alternatives for a world in crisis/neoliberal planning is not the only way: mapping the regressive tendencies of planning practice. Planning Theory \& Practice, 14(4), 529-560. 
Marlyana Azyyati Marzukhi, Oliver Ling Hoon Leh, \& Hazlina Hamdan

Urban Planning and the Challenges of Neoliberal Globalisation in Malaysia

Prior, L. F. (2008). Document analysis. In L. Given (Ed.), The Sage encyclopedia of qualitative research methods (pp. 230-232). London: Sage.

Purcell, M. (2009). Resisting neoliberalization: communicative planning or counter-hegemonic movements? Planning Theory, 8(2), 140-165.

Purcell, M. (2013). The down-deep delight of democracy. Chichester, United Kingdom: John Wiley \& Sons.

Qadeer, M. A. (2012). Urban development. In B. Sanyal, L. J. Vale \& C., D. Rosan (Eds.), Planning ideas that matter: livability, territoriality, governance, and reflective practice (pp. 207-232). London: The MIT Press.

Savin-Baden, M., \& Major, C. H. (Eds.) (2013). Qualitative Research: the essential guide to theory and practice. Oxon: Routledge.

Shoemaker, P. J., \& Reese, S. D. (2013). Mediating the Message in the 21st Century: A Media Sociology Perspective. New York: Routledge.

Taib, M. S., \& Siong, H. C. (2008, June). Planning System in Malaysia. Seminar of Sustainable Development and Governance. Toyohashi, Japan.

Tedong, P. A., Grant, J. L., Aziz, W. A., \& Azriyati, W. N. (2015). Governing enclosure: the role of governance in producing gated communities and guarded neighborhoods in Malaysia. International Journal of Urban and Regional Research, 39(1), 112-128.

Turner, M., O'Donnell, M., Suh, C., \& Kwon, S. (2013). Public sector management and the changing nature of the developmental state in Korea and Malaysia. The Economic and Labour Relations Review, 24(4), 481494.

United Nations Department of Economic (2008). The Millennium Development Goals Report 2008. United Nations Publications.

Van Assche, K., Beunen, R. \& Duineveld, M. (2014). Evolution governance theory: an introduction. London: Springer. 